\title{
An Ichthyophonus hoferi epizootic in herring in the North Sea, the Skagerrak, the Kattegat and the Baltic Sea
}

\author{
S. Mellergaard ${ }^{1}$, B. Spanggaard ${ }^{2, *}$ \\ ${ }^{1}$ Danish Institute of Fisheries Research, Department for Marine and Coastal Ecology, Fish Disease Laboratory, Bülowsvej 13, \\ DK-1870 Frederiksberg C, Denmark \\ ${ }^{2}$ Danish Institute of Fisheries Research, Department of Seafood Research, Technical University, BIdg. 221, \\ DK-2800 Lyngby, Denmark
}

\begin{abstract}
An epizootic caused by the internal parasite Ichthyophonus hoferi in herring Clupea harengus was recorded from 1991 to 1993 in the waters around Denmark. A surveillance programme from research vessels and commercial fishing boats was conducted in the North Sea, Skagerrak, Kattegat and Baltic Sea. A total of 15769 hearts of adult herring were examined macroscopically for evidence of infection. The prevalence of the infection in this period decreased from 10.6 to $2.0 \%$ in the North Sea, from 8.0 to $5.6 \%$ in the Skagerrak, from 12.0 to $1.1 \%$ in the Kattegat and from 4.5 to $0.4 \%$ in the Baltic Sea. Prevalence rates in research vessel catches were significantly higher (by 1.8 times) than in commercial fishing boat catches. The results show a high degree of temporal and spatial variation of the prevalence of $I$. hoferi. Infected fish were found to be significantly longer than unaffected fish in the North Sea and the Skagerrak. The majority of the infected fish belonged to the age groups $2+, 3+$ and $4+$ except in the commercial catches from the North Sea where most of the affected fish belonged to the age groups $5+, 6+$ and $7+$. Annual mortality in the different areas, based on the observed prevalences was roughly estimated at 12.8 to $36 \%$ in 1991, decreasing to a few percent in 1993. The spawning stock biomass of North Sea herring was reduced by $50 \%$ during the period 1990 to 1995 . This reduction may have been due to a combination of increased fishing intensity and the general effect of the I. hoferi epizootic.
\end{abstract}

KEY WORDS: Ichthyophonus hoferi Epizootic · Herring · North Sea - Skagerrak $\cdot$ Kattegat · Baltic Sea

\section{INTRODUCTION}

Ichthyophonus hoferi Plehn \& Mulsow (1911) is an internal parasite of many fish species. This microorganism was, until recently, believed to be a fungus but new investigations have shown that I. hoferi belongs to the protist kingdom (Spanggaard et al. 1996). I. hoferi causes systemic infections in fish in which the principal infection sites are the organs richly supplied with blood. The fish are believed to be infected by ingestion of spores and affected organs reveal mainly thick-walled multinucleate cells of 'resting spores' that vary in size up to $200 \mu \mathrm{m}$ in diameter.

\footnotetext{
·Addressee for correspondence. E-mail: bsp@ffl.min.dk
}

These resting spores produce aseptate hyphae immediately after death of the fish host (Dorier \& Degrange 1960, McVicar 1982)

Ichthyophonus hoferi displays a remarkable physiological adaptability to a wide range of environmental conditions and has been reported in a broad range of both fresh water and marine fish. The parasite is a potent pathogen in several important commercial fish species, e.g. herring Clupea harengus, plaice Pleuronectes platessa, haddock Melanogrammus aeglefinus and mackerel Scomber scombrus (Neish \& Hughes 1980), and, recently, an epizootic among herring in the waters around Denmark and Norway was reported (Lang 1992a, b, Rahimian \& Thulin 1996). Epizootics have previously been reported in herring in North American waters with consequential severe reductions 
in stocks (up to 50\%) (Sindermann 1970). In the North Sea, infections by 1 . hoferi have been described in haddock and plaice (McVicar 1979). Outbreaks have probably previously occurred in clupeids in Danish coastal waters as evidenced by outbreaks of ichthyophoniasis in farmed rainbow trout Oncorhynchus mykiss fed on trash fish of marine origin (Rasmussen 1967). In addition, Baltic cod developed ichthyophoriasis in an experiment in which they were held in net cages and fed on herring (Kock 1975). The infection has also been demonstrated in wild cod Gadus morhua in the Baltic Sea (Möller 1974, Reimer \& Walter 1993).

Until 1991, epizootics similar to those observed in North American waters had not been recorded in the North Sea area (apart from increased mortality in local plaice stocks observed along the Scottish coast; McVicar 1981). However, in the late summer of 1991, mass mortalities from ichthyophoniasis in Norwegian spring spawning herring were reported (Hjeltness \& Skagen pers. comm.). A few months later, the disease was recorded among herring stocks in the Kattegat and the Sound between Denmark and Sweden.

The purpose of the present study was to investigate the spatial distribution and the prevalence of the disease in European herring.

\section{MATERIALS AND METHODS}

The surveillance programme was carried out in the North Sea, the Skagerrak, the Kattegat and the Baltic Sea. Samples were collected from trawl catches of both commercial fishing boat and research vessel catches. Total numbers of 3061,3600 and 9474 herring were examined in 1991, 1992 and 1993, respectively. The fish were kept frozen until the time of processing. Of the examined fish, 9854 were length-determined and 10739 were age-determined. About one third of the herring were sex-determined. The hearts from subsamples of approximately 50 herring were inspected macroscopically. Infection with Ichthyophonus hoferi was diagnosed based on the presence of visible white nodules on the surface the heart as recommended by Anonymous (1993).

A rough estimate of the annual mortality rate of the herring stock was calculated as:

Annual mortality rate $=\frac{\text { Prevalence } \times 365 \text { (days })}{105(\text { life expectancy in days })^{-1}}$

This formula is based on the assumptions that all infected fish which are detected in a sample die of the infection within $105 \mathrm{~d}$ (Anonymous 1993). The estimate of disease rate and mortality at $100 \%$ are both based on aquarium experiments on 2000 herring (Sindermann 1958).

\section{1}

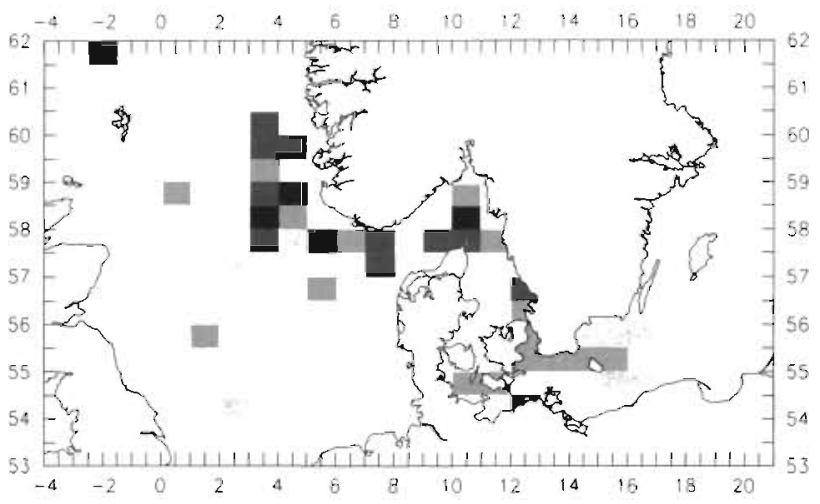

1992

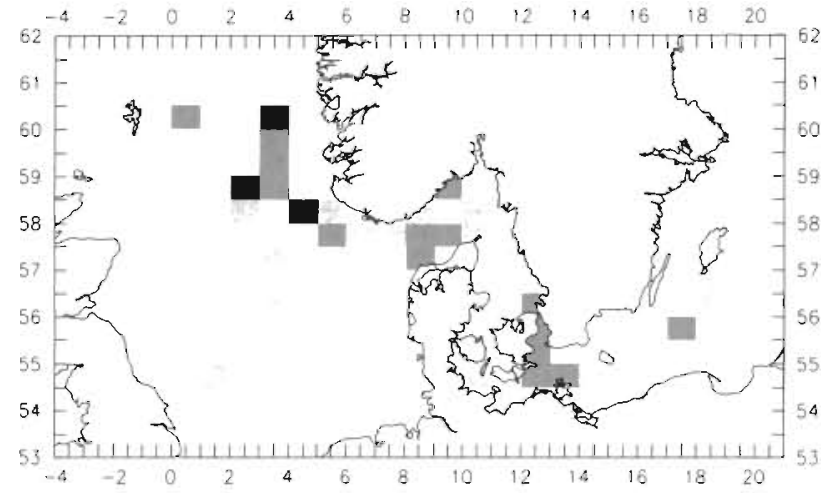

1993

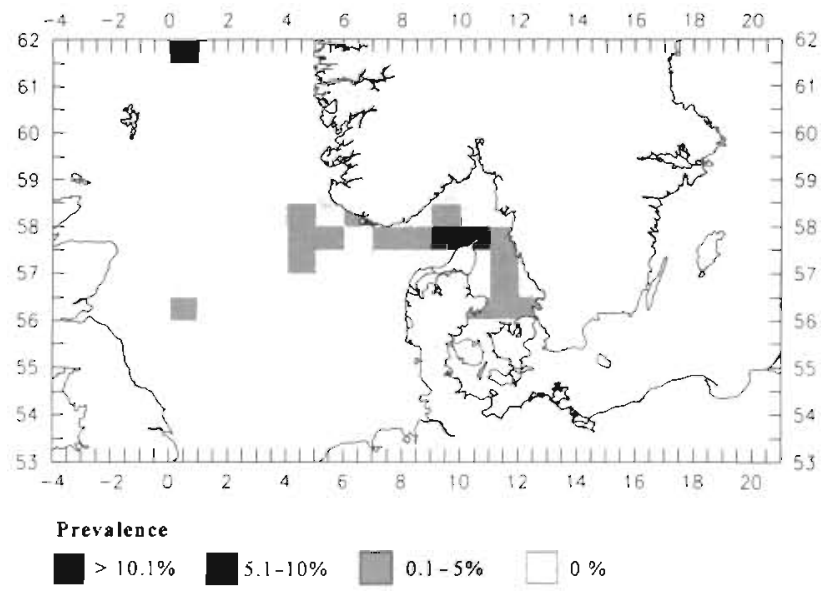

Fig. 1. Spatial distribution of sampling and the prevalence of Ichthyophonus hoferi infected herring in the North Sea, the

Skagerrak, the Kattegat and the Baltic from 1991 to 1993

Data analysis were carried out using Statistix $®$, version 4.1 (Analytical Software). The statistical tests applied for the data treatment were chi-square test, 2sample $t$-test and Mann-Whitney rank sum. test, depending on the distribution of the variables. 


\section{RESULTS}

Disease symptoms observed in the Ichthyophonus hoferi infected herring were white granuloma formations in the heart muscles. Granulomas were also observed in the liver, on the surface of the viscera and in the lateral red muscle.

Determination of the spatial distribution of Ichthyophonus hoferi infected herring was based on commercial and research vessel catches for the last 2 quarters of 1991, and the years 1992 and 1993 in the North Sea, the Skagerrak, the Kattegat and the Baltic Sea (Fig. 1). The prevalence of $I$. hoferi was at a higher level in 1991 compared to 1992 and 1993 and showed a decreasing trend from 1991 to 1993. The I. hoferi infection was observed in herring from the northern North Sea, the Skagerrak, the Kattegat and eastern Baltic Sea, while the southern North Sea (south of latitude $56^{\circ}$ ) seemed to be free of the infection. The high prevalence found in the Skagerrak in 1993 represents a series of samples of highly infected $1+$ herring.

The prevalence of Ichthyophonus hoferi was found significantly higher (1.8 times) in research vessel catches $(\mathrm{n}=11049)$ than in commercial fishing boats catches $(n=4750)(p<0.001)$. Therefore, the data from research vessel and commercial fishing boats were considered separately in the analyses.
A total of 1363 herring were examined from research vessel catches from the North Sea in the period 1991 to 1993 (Table 1). A significant decrease in the prevalence of Ichthyophonus hoferi infection from $10.6 \%$ in 1991 to $3.2 \%$ in 1992 and $0.0 \%$ in 1993 (p < $0.001)$ was observed in these catches. From commercial fishing boat catches, 2201 fish were examined and the prevalence decreased from $3.7 \%$ in 1991 to $1.8 \%$ in 1992 and $2.0 \%$ in 1993 . The observed decrease was not statistically significant. From the Skagerrak, a total of 4805 herring originating from research vessel catches were examined and, here, the infection rate decreased significantly from $8.0 \%$ in 1991 to $1.6 \%$ in $1992(p<0.001)$, whereafter the infection rate increased significantly to $5.6 \%$ in 1993 ( $p<0.001)$. This increase was due to a series of samples of highly infected $1+$ herring caught during a research vessel cruise in the beginning of May. From commercial catches, 500 fish were examined and the prevalence decreased significantly $(p<0.05)$ from $8 \%$ in 1991 to $1.3 \%$ in 1992 and, in 1993, none of the examined fish were found infected. In the Kattegat, 3131 herring originating from research vessel catches were examined and the infection rate decreased significantly from $12.0 \%$ in 1991 to $0.5 \%$ in 1992 ( $p<0.001$ ) followed by a minor increase to $1.1 \%$ in 1993 . From commercial fishing boat catches, 1050 herring were exam-

Table 1. Prevalence of Ichthyophonus hoferi infection in herring Clupea harengus in the North Sea, the Skagerrak, the Kattegat and the Baltic Sea from 1991 to 1993. Date show number of herring investigated, number aged; number infected, number aged; prevalence; estimated mortality rate

\begin{tabular}{|c|c|c|c|c|c|c|c|c|c|c|c|c|c|}
\hline \multirow[b]{2}{*}{ Area } & \multirow[b]{2}{*}{ Year } & \multicolumn{6}{|c|}{ Research vessel } & \multicolumn{6}{|c|}{ Commercial vessel } \\
\hline & & $\begin{array}{c}\text { No. } \\
\text { invest. }\end{array}$ & $\begin{array}{l}\text { No. } \\
\text { aged }\end{array}$ & $\begin{array}{c}\text { No. } \\
\text { infect. }\end{array}$ & $\begin{array}{l}\text { No. } \\
\text { aged }\end{array}$ & $\begin{array}{l}\text { Prev. } \\
(\%)\end{array}$ & $\begin{array}{l}\text { Estim. } \\
\text { mort. (\%) }\end{array}$ & $\begin{array}{c}\text { No. } \\
\text { invest. }\end{array}$ & $\begin{array}{c}\text { No. } \\
\text { aged }\end{array}$ & $\begin{array}{c}\text { No. } \\
\text { infect. }\end{array}$ & $\begin{array}{l}\text { No. } \\
\text { aged }\end{array}$ & $\begin{array}{l}\text { Prev. } \\
(\%)\end{array}$ & $\begin{array}{l}\text { Estim. } \\
\text { mort. }(\%)\end{array}$ \\
\hline \multirow[t]{3}{*}{ North Sea } & 1991 & 663 & 656 & 70 & 70 & 10.6 & 36.8 & 350 & 348 & 13 & 13 & 3.7 & 12.8 \\
\hline & 1992 & 250 & 250 & 8 & 8 & 3.2 & 11.1 & 900 & 889 & 16 & 15 & 1.8 & 6.3 \\
\hline & 1993 & 450 & 450 & 0 & 0 & 0.0 & 0.0 & 951 & 939 & 19 & 19 & 2.0 & 7.0 \\
\hline Total & $1991-93$ & 1363 & 1356 & 78 & 78 & 5.7 & 19.8 & 2201 & 2176 & 48 & 47 & 2.2 & 7.6 \\
\hline \multirow{3}{*}{ Skagerrak } & 1991 & 200 & 195 & 16 & 16 & 8.0 & 27.8 & 100 & 99 & 8 & 8 & 8.0 & 27.8 \\
\hline & 1992 & 550 & 550 & 9 & 9 & 1.6 & 5.6 & 150 & 149 & 2 & 2 & 1.3 & 4.5 \\
\hline & 1993 & 4055 & 1458 & 228 & 222 & 5.6 & 19.5 & 250 & 248 & 0 & 0 & 0.0 & 0.0 \\
\hline Total & $1991-93$ & 4805 & 2203 & 253 & 247 & 5.3 & 18.4 & 500 & 496 & 10 & 10 & 2.0 & 7.0 \\
\hline \multirow[t]{3}{*}{ Kattegat } & 1991 & 100 & 94 & 12 & 12 & 12.0 & 41.7 & 100 & 98 & 1 & 1 & 1.0 & 3.5 \\
\hline & 1992 & 200 & 200 & 1 & 1 & 0.5 & 1.7 & 350 & 349 & 5 & 5 & 1.4 & 4.9 \\
\hline & 1993 & 2831 & 450 & 32 & 3 & 1.1 & 3.8 & 600 & 595 & 0 & 0 & 0.0 & 0.0 \\
\hline Total & $1991-93$ & 3131 & 744 & 45 & 16 & 1.4 & 4.8 & 1050 & 1042 & 6 & 6 & 0.6 & 2.1 \\
\hline \multirow[t]{3}{*}{ Baltic Sea } & 1991 & 550 & 535 & 11 & 10 & 2.0 & 7.0 & 399 & 395 & 18 & 18 & 4.5 & 15.6 \\
\hline & 1992 & 850 & 844 & 9 & 9 & 1.1 & 3.8 & 350 & 350 & 14 & 14 & 4.0 & 13.9 \\
\hline & 1993 & 350 & 349 & 0 & 0 & 0.0 & 0.0 & 250 & 249 & 1 & 1 & 0.4 & 1.4 \\
\hline Total & $1991-93$ & 1750 & 1728 & 20 & 19 & 1.1 & 3.8 & 999 & 994 & 33 & 33 & 3.3 & 11.5 \\
\hline $\begin{array}{l}\text { Total } \\
\text { (all areas) }\end{array}$ & $1991-93$ & 11019 & 6031 & 396 & 360 & 3.6 & 12.5 & 4750 & 4708 & 97 & 96 & 2.0 & 7.0 \\
\hline
\end{tabular}


Table 2. Length of Ichthyophonus hoferi infected and healthy herring in the North Sea, Skagerrak, Kattegat and BaItic Sea

\begin{tabular}{|c|c|c|c|c|c|c|c|c|c|c|c|c|c|c|c|c|}
\hline \multirow[b]{2}{*}{$\begin{array}{l}\text { Length } \\
(\mathrm{cm})\end{array}$} & \multicolumn{4}{|c|}{ North Sea } & \multicolumn{4}{|c|}{ _ Skagerrak } & \multicolumn{4}{|c|}{$\longrightarrow$ Kattegat } & \multicolumn{4}{|c|}{$\ldots$ Baltic Sea } \\
\hline & $\begin{array}{l}\text { Rese } \\
\text { Total }\end{array}$ & $\begin{array}{l}\text { arch } \\
\text { Infect. }\end{array}$ & $\begin{array}{l}\text { Comr } \\
\text { Total }\end{array}$ & $\begin{array}{l}\text { mercial } \\
\text { Infect. }\end{array}$ & $\begin{array}{r}\text { Res } \\
\text { Total }\end{array}$ & $\begin{array}{l}\text { earch } \\
\text { Infect. }\end{array}$ & $\begin{array}{l}\text { Com } \\
\text { Total }\end{array}$ & $\begin{array}{l}\text { mercial } \\
\text { Infect. }\end{array}$ & $\begin{array}{l}\text { Rese } \\
\text { Total }\end{array}$ & $\begin{array}{l}\text { earch. } \\
\text { Infect. }\end{array}$ & $\begin{array}{l}\text { Comn } \\
\text { TotaI }\end{array}$ & $\begin{array}{l}\text { mercial } \\
\text { Infect. }\end{array}$ & $\begin{array}{l}\text { Rese } \\
\text { Total }\end{array}$ & $\begin{array}{l}\text { earch } \\
\text { Infect. }\end{array}$ & $\begin{array}{l}\text { Comn } \\
\text { Total }\end{array}$ & $\begin{array}{l}\text { mercial } \\
\text { Infect. }\end{array}$ \\
\hline$<10$ & 10 & 0 & 0 & 0 & 0 & 0 & 0 & 0 & 0 & 0 & 0 & 0 & 2 & 0 & 2 & 0 \\
\hline $10-14.9$ & 1 & 0 & 0 & 0 & 96 & 0 & 0 & 0 & 29 & 0 & 0 & 0 & 239 & 1 & 52 & 2 \\
\hline $15-19.9$ & 286 & 4 & 6 & 0 & 287 & 0 & 19 & 0 & 371 & 0 & 104 & 0 & 770 & 7 & 176 & 4 \\
\hline $20-24.9$ & 640 & 24 & 581 & 4 & 688 & 22 & 259 & 2 & 308 & 15 & 615 & 3 & 601 & 9 & 361 & 13 \\
\hline $25-29.9$ & 405 & 49 & 1385 & 28 & 178 & 5 & 207 & 6 & 42 & 1 & 316 & 3 & 137 & 3 & 395 & 14 \\
\hline$>30$ & 14 & 1 & 228 & 16 & 1 & 0 & 15 & 2 & 0 & 0 & 15 & 0 & 0 & 0 & 13 & 0 \\
\hline
\end{tabular}

ined and the prevalence was $1.0 \%$ in $1991,1.4 \%$ in 1992 and $0.0 \%$ in 1993. Finally, in the Baltic Sea, a total of 1750 herring from research vessel catches were inspected for the infection. Here the prevalence decreased from $2.0 \%$ in 1991 to $0.0 \%$ in 1993 . The contribution from commercial catches was 999 herring and the prevalence was $4.5 \%$ in 1991 and $4.0 \%$ in 1992 followed by a significant decrease $(\mathrm{p}<0.05)$ to $0.4 \%$ in 1993.

A subsample of herring was sex-determined (2579 males and 2878 females) and the Ichthyophonus hoferi infection was found to be evenly distributed between males and females (chi-square).

Length distributions for Ichthyophonus hoferi infected and healthy herring in the North Sea, the Skagerrak, the Kattegat and the Baltic Sea are illustrated in Table 2 and in Fig. 2a for research vessel catches and Fig. $2 b$ for commercial fishing boat catches. Herring originating from research vessel catches were within the length range 10 to $30 \mathrm{~cm}$ and the $I$. hoferi infected specimens were within the range 20 to $30 \mathrm{~cm}$, except for the Baltic Sea, where the length distribution of infected fish reflects the distribution of the unaffected stock. The commercial herring catches were within the range from 15 to $35 \mathrm{~cm}$ and the $I$. hoferi affected fish were from 21 to $35 \mathrm{~cm}$ in the North Sea, the Skagerrak and the Kattegat while the length distribution in commercial catches from the Baltic Sea displayed a similar pattern to those observed for the research vessel catches.

The infected herring originating from research vessel catches from the North Sea, the Skagerrak and the Kattegat were significantly longer than the healthy fish ( $p<0.01, t$-test) (Table 3 ) while no significant difference in the length of the fish between the 2 groups was observed in the Baltic Sea. However, when selecting fish longer than $20 \mathrm{~cm}$ (which included most infected fish), only infected herring from the North Sea were found to be significantly longer $(p<0.001)$ than uninfected fish. By further restricting the analyzed length

Table 3. Clupea harengus. Distribution of length ( $t$-test) and age (rank sum test) of Ichthyophonus hoferi infected herring in the North Sea, Skagerrak, Kattegat and Baltic Sea from 1991 to 1993. nd: not determined. Level of significance: ${ }^{*}<<0.05 ;{ }^{*} p<0.01$; $\cdots p<0.001$

\begin{tabular}{|c|c|c|c|c|c|c|c|c|c|}
\hline \multirow[b]{2}{*}{ Length mean $(\mathrm{cm})$} & \multirow{2}{*}{$\begin{array}{c}\text { Infected } \\
\qquad \begin{array}{c} \\
- \\
+\end{array}\end{array}$} & \multicolumn{2}{|c|}{$\begin{array}{c}\text { North Sea } \\
\text { Research Commercial }\end{array}$} & \multicolumn{2}{|c|}{$\begin{array}{c}\text { Skagerrak } \\
\text { Research Commercial }\end{array}$} & \multicolumn{2}{|c|}{$\begin{array}{c}\text { Kattegat } \\
\text { Research Commercial }\end{array}$} & \multicolumn{2}{|c|}{$\begin{array}{c}\text { Baltic Sea } \\
\text { Research Commercia }\end{array}$} \\
\hline & & $\begin{array}{l}22.7 \\
25.6 \cdots\end{array}$ & $\begin{array}{l}26.8 \\
28.8 \cdots\end{array}$ & $\begin{array}{l}21.4 \\
23.5 \cdots\end{array}$ & $\begin{array}{l}24.6 \\
26.5^{\circ}\end{array}$ & $\begin{array}{l}19.9 \\
22.3 \cdots\end{array}$ & $\begin{array}{l}23.6 \\
24.5\end{array}$ & $\begin{array}{l}19.2 \\
20.7\end{array}$ & $\begin{array}{l}23.0 \\
23.2\end{array}$ \\
\hline $\begin{array}{l}\text { Length mean }(\mathrm{cm}) \\
\text { (length }>20 \mathrm{~cm})\end{array}$ & $\begin{array}{l}- \\
+\end{array}$ & $\begin{array}{l}24.0 \\
25.9 \cdots\end{array}$ & $\begin{array}{l}26.8 \\
28.8 \cdots\end{array}$ & $\begin{array}{l}23.3 \\
23.5\end{array}$ & $\begin{array}{l}24.8 \\
26.4^{\circ}\end{array}$ & $\begin{array}{l}22.6 \\
22.3\end{array}$ & $\begin{array}{l}24.1 \\
24.5\end{array}$ & $\begin{array}{l}22.8 \\
23.0\end{array}$ & $\begin{array}{l}24.8 \\
24.7\end{array}$ \\
\hline $\begin{array}{l}\text { Length mean }(\mathrm{cm}) \\
\text { (length }>25 \mathrm{~cm} \text { ) }\end{array}$ & + & $\begin{array}{l}27.0 \\
27.1\end{array}$ & $\begin{array}{l}28.1 \\
29.3 \ldots\end{array}$ & $\begin{array}{l}26.1 \\
26.4\end{array}$ & $\begin{array}{l}27.1 \\
27.4\end{array}$ & $\begin{array}{l}\text { nd } \\
\text { nd }\end{array}$ & $\begin{array}{l}26.9 \\
26.5\end{array}$ & $\begin{array}{l}26.4 \\
26.9\end{array}$ & $\begin{array}{l}26.9 \\
27.1\end{array}$ \\
\hline Age (yr) & $\begin{array}{l}- \\
+\end{array}$ & $\begin{array}{l}2.2 \\
2.9 \cdots\end{array}$ & $\begin{array}{l}3.7 \\
5.2 \cdots\end{array}$ & $\begin{array}{l}2.1 \\
2.0\end{array}$ & $\begin{array}{l}2.6 \\
3.0\end{array}$ & $\begin{array}{l}1.7 \\
2.1\end{array}$ & $\begin{array}{l}2.9 \\
3.3\end{array}$ & $\begin{array}{l}2.3 \\
2.8\end{array}$ & $\begin{array}{l}3.4 \\
3.5\end{array}$ \\
\hline $\begin{array}{l}\text { Age }(y r) \\
(\text { length }>20 \mathrm{~cm})\end{array}$ & $\overrightarrow{+}+$ & $\begin{array}{l}2.5 \\
3.0\end{array}$ & $\begin{array}{l}3.7 \\
5.2 \cdots\end{array}$ & $\begin{array}{l}2.8 \\
2.0 \cdots\end{array}$ & $\begin{array}{l}2.6 \\
3.0\end{array}$ & $\begin{array}{l}2.5 \\
2.1\end{array}$ & $\begin{array}{l}3.1 \\
3.3\end{array}$ & $\begin{array}{l}3.7 \\
3.7\end{array}$ & $\begin{array}{l}4.0 \\
4.0\end{array}$ \\
\hline $\begin{array}{l}\text { Age }(y r) \\
\text { (length }>25 \mathrm{~cm})\end{array}$ & $\begin{array}{l}- \\
+\end{array}$ & $\begin{array}{l}3.7 \\
3.4\end{array}$ & $\begin{array}{l}4.4 \\
5.4 \cdots\end{array}$ & $\begin{array}{l}4.1 \\
2.4\end{array}$ & $\begin{array}{l}3.7 \\
3.1\end{array}$ & $\begin{array}{l}\text { nd } \\
\text { nd }\end{array}$ & $\begin{array}{l}4.4 \\
4.3\end{array}$ & $\begin{array}{l}4.9 \\
5.0\end{array}$ & $\begin{array}{l}4.6 \\
4.7\end{array}$ \\
\hline
\end{tabular}



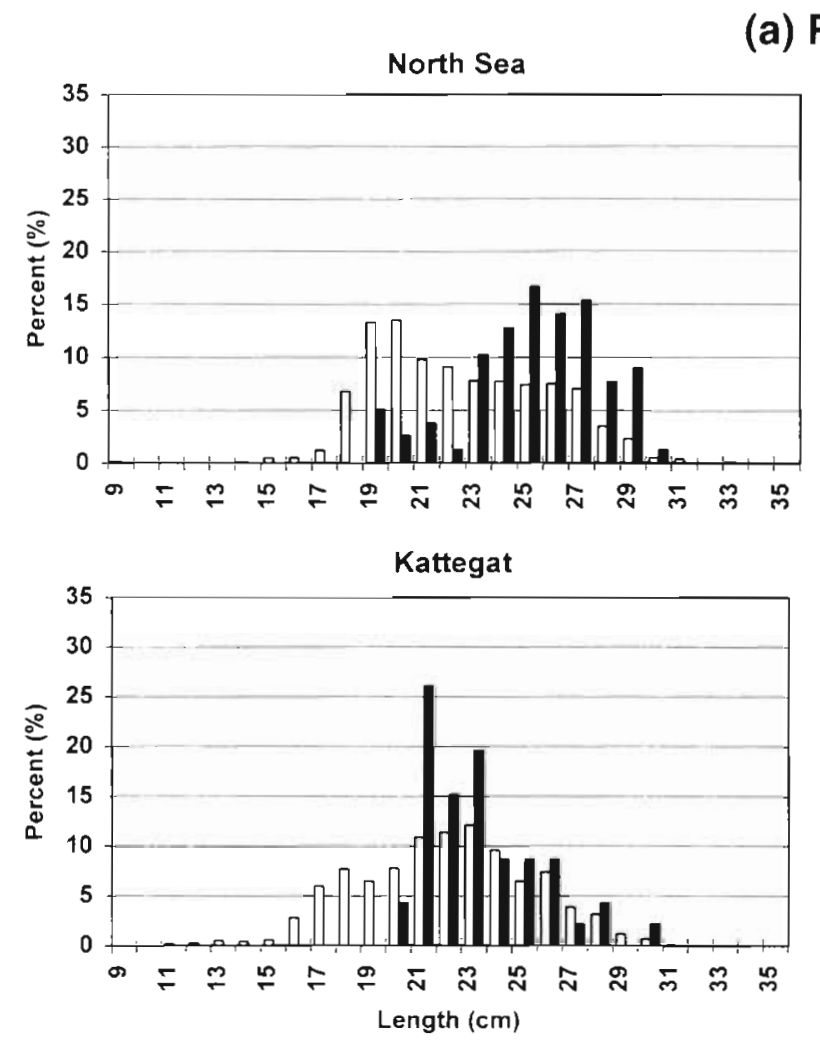

(a) Research
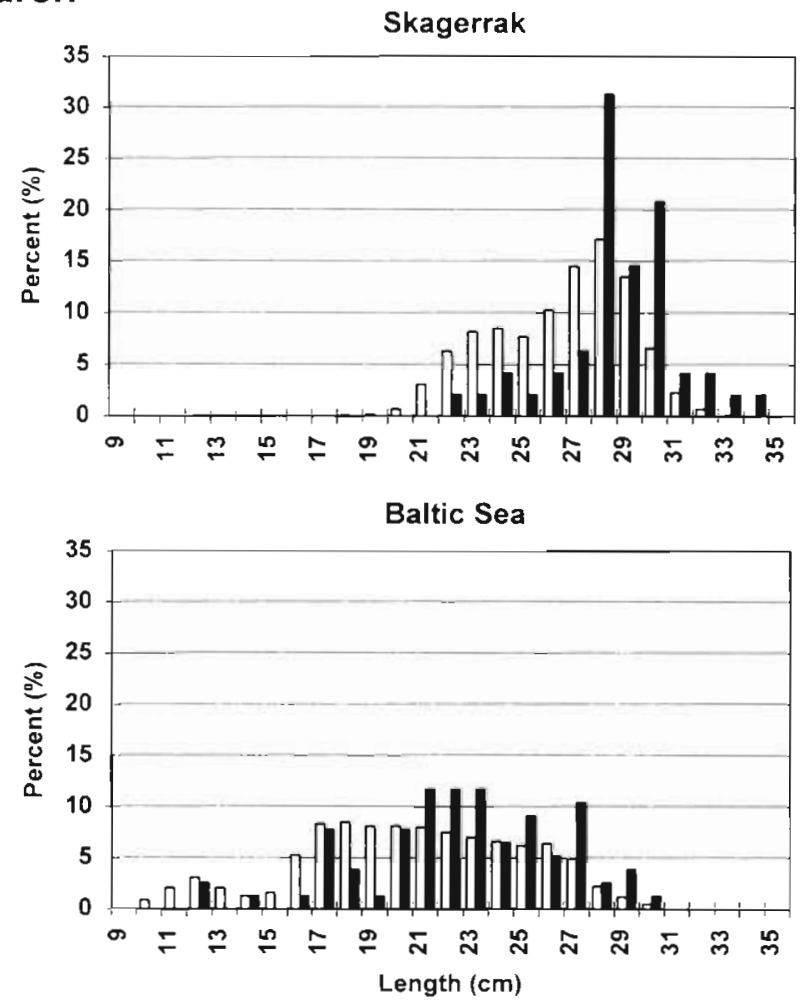

(b) Commercial
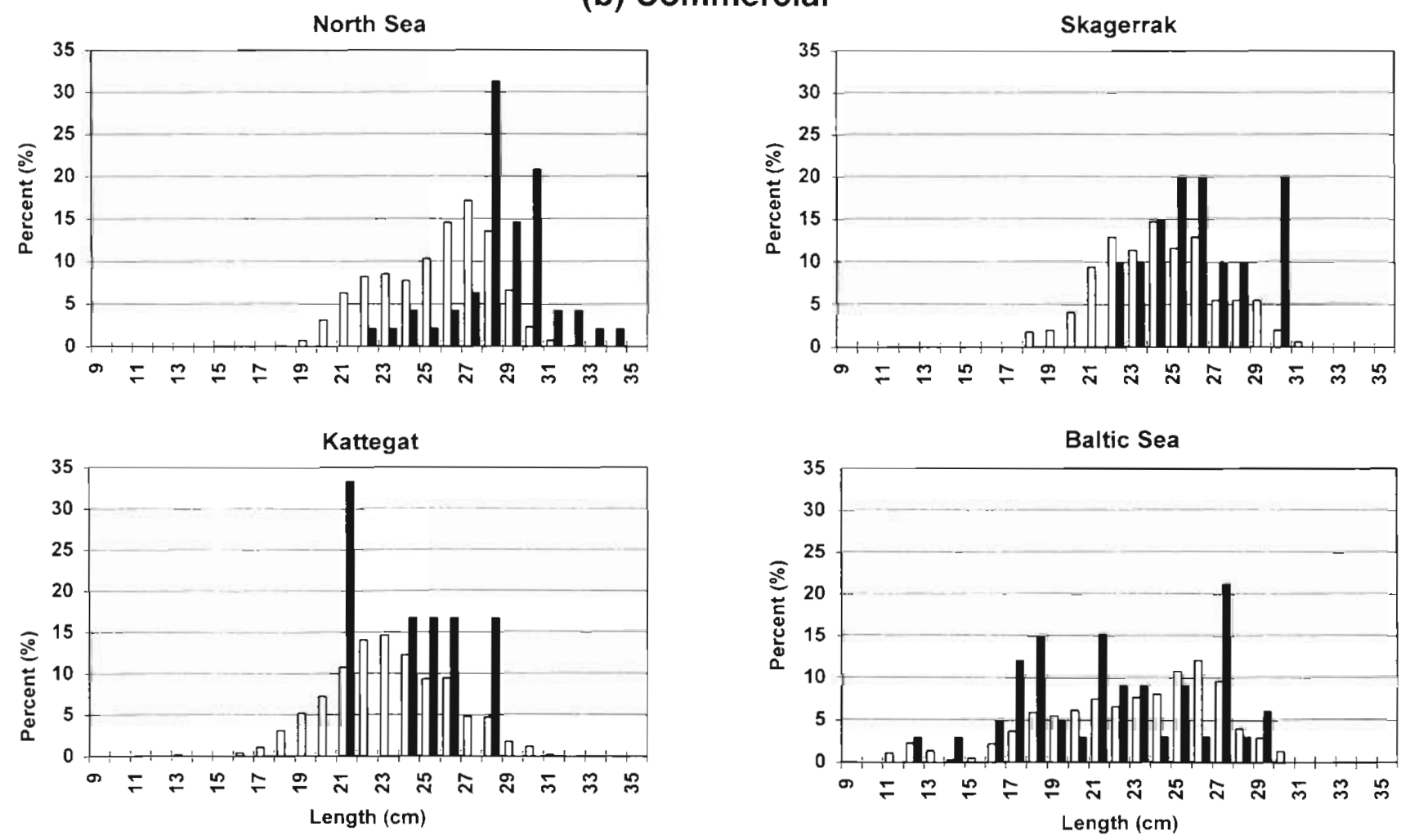

Fig. 2. Clupea harengus. Length composition expressed in percentages of infected (black bars) and uninfected (open bars) herring, respectively, for the North Sea, the Skagerrak, the Kattegat and the Baltic Sea. (a) Research vessel catches, (b) commercial fishing boat catches 


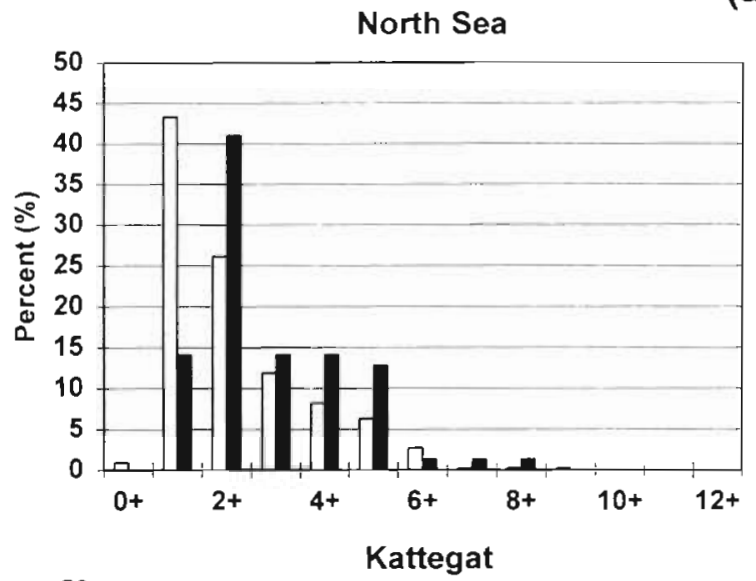

(a) Research
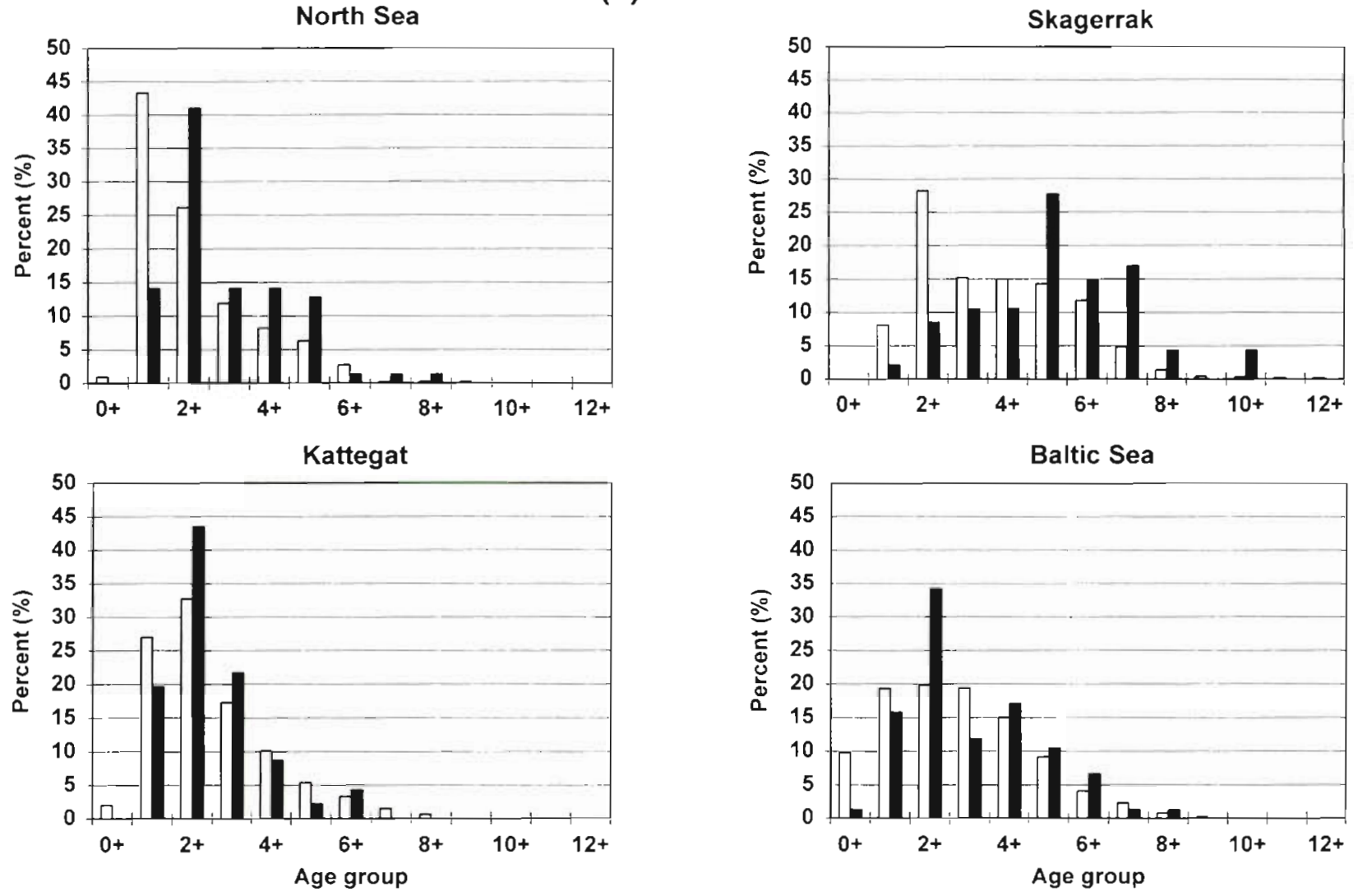

(b) Commercial
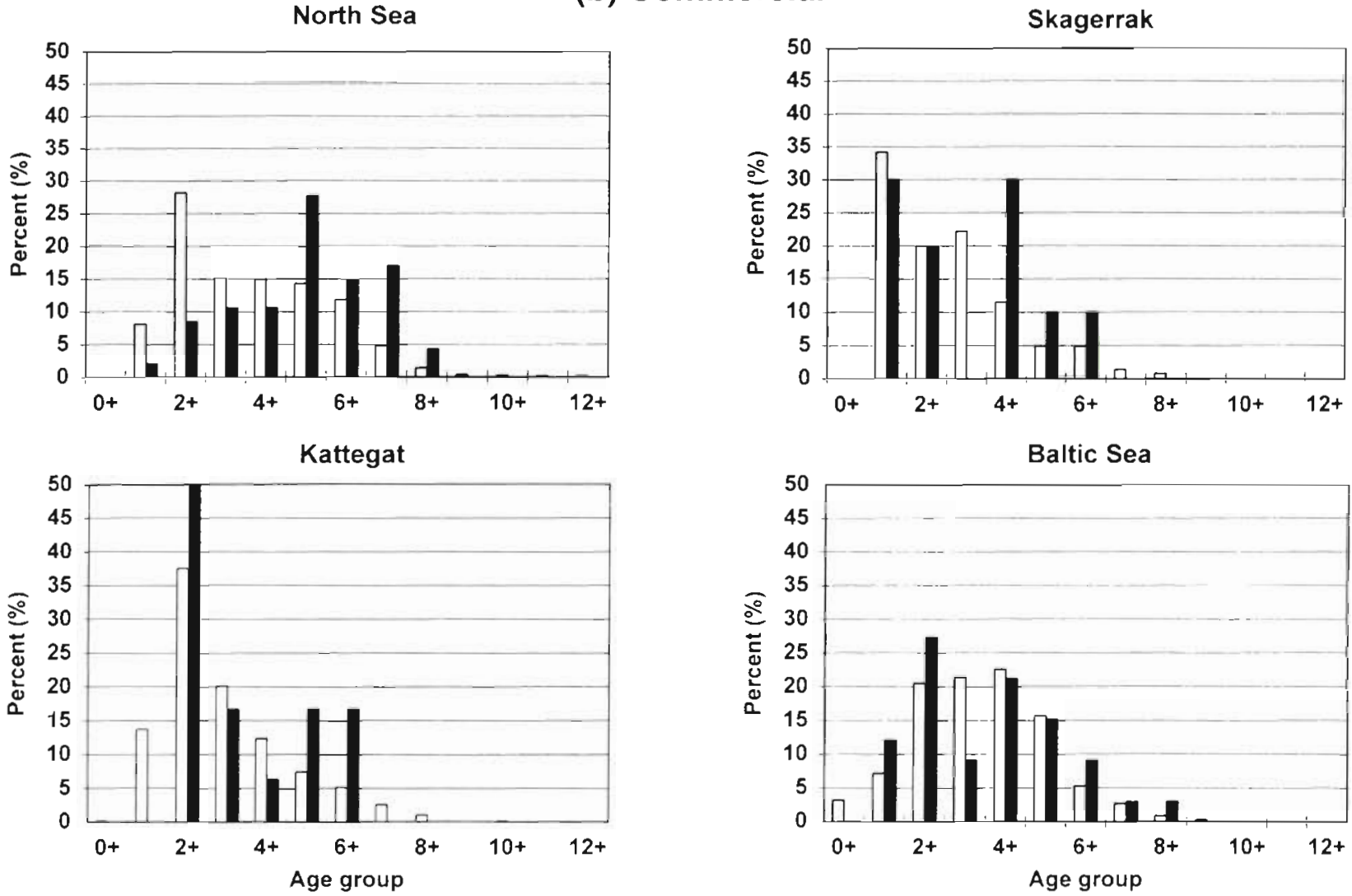

Fig. 3. Cluped harengus. Age composition expressed in percentages of infected (black bars) and uninfected (open bars) herring. respectively, for the North Sea, the Skagerrak, the Kattegat and the Baltic Sea. (a) research vessel catches, (b) commercial fish- 
group to fish longer than $25 \mathrm{~cm}$, the significant length difference between the diseased and healthy fish disappeared from the North Sea. For the commercial catches, the infected herring were significantly longer ( $p<0.05, t$-test) in the North Sea and the Skagerrak than the uninfected specimens. This also applied to the length interval longer than $20 \mathrm{~cm}$. This difference remained for the North Sea herring when the length group was further restricted to fish longer than $25 \mathrm{~cm}$. No significant difference between the lengths of infected and uninfected herring was observed in the Kattegat and the Baltic Sea.

The age compositions expressed in percentages of infected and healthy herring for the North Sea, the Skagerrak, the Kattegat and the Baltic Sea are illustrated in Fig. 3a for research vessel catches and Fig. 3b for commercial catches. In general, the age interval of infected fish reflected the distribution of the healthy stock for both research and commercial boat catches. The majority of the infected fish belonged to the age groups $1+, 2+$ and $3+(45$ to $90 \%)$ while the remainder of the affected fish were distributed within the range from $1+$ to $12+$ except in the commercial catches from the North Sea, in which most of the affected fish belonged to the age groups $5+, 6+$ and $7+(60 \%)$. In the North Sea, the mean age of infected fish was significantly higher than that of the healthy fish $(p<0.01)$ for both research and commercial boat catches. In contrast, the infected herring were found to be significantly younger than unaffected fish $(p<0.05)$ in research vessel catches from the Skagerrak. The other areas did not show any differences in the age composition of healthy and diseased herring (Table 2).

The estimate of the annual mortality based on the observed prevalences in the different areas ranged from 3 to $42 \%$ in 1991, 2 to $14 \%$ in 1992 and from 0 to $7 \%$ in 1993, except for the Skagerrak, where the heavily infected samples of $1+$ herring influenced the results, suggesting a mortality of $19 \%$ (Table 1 ).

\section{DISCUSSION}

The disease symptoms observed during this study were similar to the those described by Sindermann \& Scattergood (1954) during outbreaks of Ichthyophonus hoferi in North American herring stocks. From 1991 to 1993, the prevalence decreased to a level below $1 \%$ in most areas. The results show a high degree of temporal as well as spatial variation of the prevalence. These variations may reflect the fact that there was no systematic sampling of herring during the period of investigation and that the data originate from both commercial landings and research vessel catches. The significant difference between the prevalences ob- served in research vessel catches and commercial fishing boat catches may be explained by the fact that commercial fishing boats fish on dense concentrations of fish while research vessels tend to fish on a more or less fixed station pattern. This interpretation is supported by Hjeltness \& Skagen (1992), who indicated that infected herring tend to be scattered instead of forming dense shoals.

The presence of a series of different herring stocks in the investigated areas is an additional factor contributing to the variation of the results. In the North Sea, 3 stocks of autumn spawners are present throughout the year. Two of these are confined to the central and northern North Sea, where they undertake an annual migration between areas of feeding, spawning and overwintering, while the third stock spawns in the southern Bight in the late autumn/early winter and keeps within the southern and central North Sea (Parrish \& Saville 1965, Popp Madsen pers. comm.). The northern North Sea is also visited by components of 2 spring spawning stocks: the Norwegian Spring spawning herring stock, which is present along the Norwegian west coast during the spawning time from approximately January to February, and spawners from local stocks in the Kattegat. Additionally, Rügen herring $(\geq 2+)$ from the western Baltic undertakes a feeding migration to the Skagerrak and adjacent parts of the North Sea in the period from May to August. The Skagerrak and the Kattegat are mainly transition areas. The Skagerrak is a nursery area for young immature herring $(0+$ and $1+)$ progeny of autumn spawners from the North Sea, while adults $(\geq 2+)$ are spring spawners from the Rügen stock. The western Baltic, Belt Seas and the Sound are dominated by the Rügen stock overwintering in the latter and spawning in the western Baltic in January to April. Young herring from the Rügen spawning are found as far east as Bornholm and spread northwards into the Kattegat with increasing age $(1+$ to $2+)$. The eastern Baltic (i.e. east of Bornholm) is inhabited by a number of almost exclusively spring-spawning stocks. Their migrations are restricted to the eastern Baltic, though some overlapping with Rügen herring may take place in the waters around Bornholm.

The age composition of infected fish reflected the composition of the healthy stock for both research and commercial boat catches. The majority of the infected fish belonged to the younger age classes $(1+$ to $3+)$. In the North Sea, however, most of the infected fish from the commercial boats belonged to the age groups $5+$ to $7+$. This observation may be due to the fact that most of the commercial catches originated from the west coast of Norway, resulting in catches containing a large proportion of Norwegian spring spawners. In the Skagerrak, most of the infected fish probably belonged to the 
North Sea herring stock as approximately $80 \%$ of the affected fish were young $(1+$ or $2+)$ (Fig. $3 a, b)$. The older affected fish may belong to parts of the Kattegat stocks as well as the Rügen herring stock. The main contribution to the increase in the prevalence from 1992 to 1993 (from 1.6 to $5.6 \%$ ) originated from samples of $1+$ herring probably belonging to the North Sea stock. As it is expected that most Ichthyophonus hoferi infected fish die of the disease (Sindermann \& Scattergood 1954), high infection level in the young age groups might seriously influence the future size of the North Sea herring stocks. In the Kattegat, approximately $50 \%$ of the infected fish were $1+$ and $2+$ (Fig. 3a, b). This result suggests that these young infected fish belong to the local herring stocks while a proportion of $5+$ and $6+$ infected fish $(35 \%$ ) observed in the commercial catches probably originated from the Rügen herring as it is only the older fish of this stock $(>2+)$ that migrate through the Kattegat area. Most of the herring samples investigated from the Baltic Sea originated from the western part and, therefore, mainly include representatives of the Rügen herring stock. However, the infection was also observed in the Baltic herring stock in 1992 in a sample collected south of Gotland (Fig.1).

Ichthyophonus hoferi infected fish were found to be significantly longer than unaffected fish in the North Sea, the Skagerrak and in research catches from the Kattegat (Table 2). After excluding the group of herring below $20 \mathrm{~cm}$ (mainly representing $1+$ ) which showed a low infection rate, the mean length of the infected fish from the North Sea and from the Skagerrak (commercial catches) was still significantly longer than the unaffected group. Further, among the infected herring, 15 to $30 \%$ belonged to the $1+$ group (Fig. 3a, b). The combination of these 2 results indicates that the infected fish belonged to the fastergrowing part of the stock. Other observations of a positive correlation between prevalence of $I$. hoferi and length have previously been reported for plaice, haddock (McVicar 1979) and herring (Lang 1992a, b). Support for this argument is that larger fish have a higher food consumption rate and, therefore, are more likely to eat infected material. The hypothesis is further supported by infection experiments showing that both heavy doses and repeated exposure to $I$. hoferi were needed to achieve infection (Sindermann 1958).

The results of the macroscopic examination method for estimating the prevalence of Ichthyophonus hoferi correspond well with those obtained with the microscopic observations in haddock and plaice (McVicar 1979). In a methodology study conducted on 668 herring, Holst (1994) observed an approximately $10 \%$ higher detection level by microscopic examination of squash preparations of heart tissue than by macro- scopic examination. This corresponds with our observations in a preliminary study (unpubl.). In contrast, Rahimian \& Thulin (1996) detected an approximately 4 times higher infection level in herring when using microscopic examination of heart tissue compared to macroscopic examination. During the present study, the detection of $I$. hoferi infection was carried out entirely by macroscopic observation as we regarded the $10 \%$ underestimation as being within an acceptable level of accuracy. Therefore, the prevalences presented in this paper may have been underestimated. However, the macroscopic examination enabled the investigation of a much larger number of samples.

It is always difficult to evaluate the effect of an epizootic when dealing with migratory fish species (like herring) as it is impossible to follow the same shoal for a long period. As a result, demonstration of increased mortality will always be based on circumstantial evidence. It must be emphazised that the rough estimate applied for the calculation of Ichthyophonus hoferi induced mortality does not account for predation. The predation of infected herring may be increased due to impaired condition of the fish and behavioural changes (Hjeltness \& Skagen 1992).

During an epizootic in herring in the Gulf of St. Lawrence from 1955 to 1957, the prevalence of Ichthyophonus hoferi infection varied from 27 to $10 \%$ (Sindermann 1958). According to analyses of data on herring landings from the Gulf of St. Lawrence, Tibbo \& Graham (1963) estimated that this I. hoferi epizootic resulted in a $50 \%$ reduction of the herring stock. The present study revealed a prevalence of $3.7 \%$ in commercial boat catches in 1991 and $10.6 \%$ in research vessel catches in the North Sea. These prevalences were estimated to contribute a mortality between 12.8 and $36.8 \%$ in the North Sea herring population in 1991 to 1992 . The prevalences were reduced in the following 2 years with a consequently lower mortality rate. The spawning stock biomass of North Sea herring showed a reduction of approximately 25\% from 1991 to 1992 (ICES 1996). Furthermore, the most recent data on the development of the size of the herring stock in the North Sea demonstrated a $50 \%$ reduction in the spawning stock biomass from 1.1 million tons in 1990 (preepizootic) to 0.5 million tons in 1995 (post-epizootic) (ICES 1996). This reduction is probably a combination of mortality in the spawning stock and in the recruits (the 1- and 2-yr old fish) as well as an increased fishing effort. The ICES Advisory Committee on Fishery Management did not find clear indications of a general recruitment failure but the fishing intensity increased during the period 1990 to 1995 (ICES 1996). Thus the reduction in the spawning stock biomass may be due to a combination of increased fishing intensity and the general effect of the $I$. hoferi epizootic. 
Acknowledgements. We thank Stina Bilstrup and Gitte Skov for excellent technical assistance, Jens Pedersen and Karl Johan Stæhr for collecting samples for the project and the crew of RV 'Dana' for collaboration during the surveys. Drs Alasdair McVicar and K. Popp Madsen are acknowledged for commenting on the manuscript. We thank Dr Katherine Richardson for linguistic corrections. The project was funded by the Danish Ministry of Agriculture and Fisheries.

\section{LITERATURE CITED}

Anonymous (1993) Report of the second special meeting on Ichthyophonus in herring. Comm Meet Int Coun Explor Sea CM-ICES 1993/F:9

Dorier A, Degrange C (1960) L'evolution de l'Ichthyosporidium (Ichthyophonus) hoferi (Plehn et Mulsow) chez les salmonides d'élevage (truite arc en ciel et saumon de fontaine). Trav Lab Hydrobiol Piscic Univ Grenoble 52: $7-44$

Hjeltnes B, Skagen DW (1992) Ichthyophonus hoferi disease in the herring in Norwegian waters. Comm Meet Int Coun Explor Sea CM-ICES 1992/H:27

Holst JC (1994) The precision of two macroscopic screening procedures relative to a microscopic procedure for screening of the fungus Ichthyophonus hoferi in herring (Clupea harengus L.). Fish Res 19:187-190

ICES (1996) Stocks in the North Sea, herring and sprat. Extract of the report on the Advisory Committee on Fishery Management, May 1996

Kock KH (1975) Uber die Haltung von Dorschen (Gadus morhua L.) in Netzkäfigen. Arch FischWiss 26:35-48

Lang T (1992a) Results of macroscopical examination on the occurrence of IChthyophonus sp. in herring (Clupea harengus) of the Baltic and North Sea. Comm Meet Int Coun Explor Sea CM-ICES 1992/F:7

Lang $T$ (1992b) Untersuchungen zum Befall von Heringen mit Ichthyophonus. Infn Fischw 39:79-89

McVicar AH (1979) Ichthyophonus in haddock and plaice in Scottish waters. Comm Meet Int Coun Explor Sea

Responsible Subject Editor: D. W. Bruno, Aberdeen, Scotland

\section{CM-ICES $1979 / \mathrm{G}: 48$}

McVicar A.H (1981) An assessment of /chthyophonus disease as a component of natural mortality in plaice populations in Scottish waters. Comm Meet Int Coun Explor Sea CMICES 1981/G:49

McVicar AH (1982) Ichthyophonus infections in fish. In: Roberts RJ (ed) Microbial diseases of fish. Academic Press, London, p 243-269

Möller H (1974) Ichthyosporidium hoferi (Plehn et Mulsow) (Fungi) as a parasite in Baltic cod Gadus morhua. Kiel Meeresforsch 30:37-41

Neish GA, Hughes GC (1980) Fungal diseases of fishes. In: Snieszko SF, Axelrod HR (eds) Diseases of fishes. Bk 6. TFH Publications, Neptune, NJ, p 61-100

Parrish BB, Saville A (1965) The biology of the North-East Atlantic herring populations. Oceanogr Mar Biol Ann Rev 3:323-373

Rahimian H, Thulin J (1996) Epizootiology of Ichthyophonus hoferi in herring populations off the Swedish west coast. Dis Aquat Org 27: 187-195

Rasmussen CJ (1967) Håndbog i orredopdræt. Rhodos International Science Publishers, Copenhagen (in Danish)

Reimer LW, Walter U (1993) Zur Parasitierung von Gadus morhua in der südlichen Ostsee. Appl Parasitol 34: $143-150$

Sindermann CJ (1958) An epizootic in the Gulf of St. Lawrence fishes. Trans N Am Wild Conf 23:349-360

Sindermann CJ (1970) Principal diseases of marine fish and shellfish. Academic Press, New York

Sindermann CJ, Scattergood LW (1954) Diseases of fishes of the Western North Atlanic. II. Ichthyosporidium disease in herring (Clupea harengus). Maine Dep Sea Shore Fish Res Bull 19:1-40

Spanggaard B, Skouboe P, Rossen L, Taylor JW (1996) Phylogenetic relationships of the intercellular fish pathogen Ichthyophonus hoferi and fungi, choanoflagellates and the rosette agent. Mar Biol 126:109-115

Tibbo SN, Graham TR (1963) Biological changes in herring stocks following an epizootic. J Fish Res Bd Can 20: $435-449$

Manuscript first received: June 3, 1996

Revised version accepted: October 29, 1996 